\title{
Are the Rules of Classical Epidemiology Valid Today?
}

\author{
Béla Ralovich \\ Ministry of Welfare (Retired), Budapest, Hungary \\ Email: ralovich.b@gmail.com
}

How to cite this paper: Ralovich, B. (2022) Are the Rules of Classical Epidemiology Valid Today? Open Journal of Applied Sciences, 12, 216-223.

https://doi.org/10.4236/ojapps.2022.122015

Received: December 23, 2021

Accepted: February 18, 2022

Published: February 21, 2022

Copyright (c) 2022 by author(s) and Scientific Research Publishing Inc. This work is licensed under the Creative Commons Attribution International License (CC BY 4.0).

http://creativecommons.org/licenses/by/4.0/

(c) (i)

\begin{abstract}
Both HIV and COVID-19 infections show that the centuries-old scientifically established epidemiological rules are still valid today, but they have to be applied in time and in a correct manner. Furthermore, when incompetent funded "rights defenders" or political organizations referring to human rights have spread lies and have spoken against the experts-created epidemiological rules as well as the acceptance of vaccination, they have not only cheated everybody but they could also be accused by the crime of endangering of great mass of people which action can cause occasionally death also! It has to be also stated that the interests and rights of the total population are always over that of a single person and also realized that all pathogens live their own life among us according to their determinacy independently from our rights and interests!
\end{abstract}

\section{Keywords}

Infectious Diseases, Epidemiology, Epidemiological Experts, Rules and Restrictions, Incompetent Persons, Vaccination, Human Rights, Interests of the Total Population

\section{Introduction}

Epidemiology is a science that covers communicable and non-communicable diseases. Epidemiologists study the causes of these diseases, the ways in which their causes spread as well as the ways on which spreading of the causes can be stopped. They determine the methods of prevention of the development of those diseases as well as ultimately, the possibility of total elimination of the causes. These experts, like researchers of other different sciences, make their decisions on the basis of the same principles-observation, experimentation and summation of the experiences, data and results. The rules of epidemiology are almost as 
old as the recognition of infectious diseases and go back thousands of years.

If we study the history and the possibilities of epidemiological control methods we can realize that they have always meant different restrictions (isolation, ban on leaving the place of residence, territorial quarantine, exclusion from civil life or occupation)-for example during the last tick typhus outbreak in Hungary during the 50s, the affected settlement was surrounded and guarded by armed policemen under the direction of the competent medical officer to prevent that nobody can enter or leave the village) - by regulations (hygienic and cleanliness rules, disinfection, compulsory testing and contact investigation, further punishment of the lawbreakers) and by compulsory use of vaccines [1] [2] [3] [4].

\section{Materials and methods}

This work is a retrospective study on the basis of the relevant literary data.

\section{Presentation of the Problems and Our Opinion}

Now we present the lessons learned from two infectious diseases which give the answer to the question readable in the title. One of them is the HIV infection/AIDS disease, the other is the currently raging COVID-19 pandemia.

\subsection{The Question of the HIV Infection/AIDS Disease}

One of them is the HIV infection/AIDS disease, the other is the currently raging COVID-19 pandemia. HIV started to spread in the 1980s in a somewhat unique way, mainly among homosexuals and intravenous drug users. Our domestic experts acted in time to identify what needs to be done and to create the necessary legislation, based on the previous successful epidemiological experiences and results of other infectious diseases. This decree caused a huge uproar among the affected persons and the members of the Hungarian Society for Human Rights(in Hungarian TASZ) which is a non-governmental organization (NGO) with great amount of support from abroad-representing their interests. You can get a picture about their activity and the events from their own report written by Csernus Eszter [5].

"When, just over a year ago, the TASZ decided to devote its next Bulletin to the subject of HIVI AIDS in Hungary, it was not yet possible to foresee, that serious changes which in the Hungarian HIVIAIDS rules would soon take place. The Decree of infectious diseases in force at that time was amended essentially only once since its acceptance of 1988, in 1998 when the legislator abolished the possibility of anonymous screening and introduced the new 'partially anonymous' screening system, under which the person applying for screening could only receive his/her result anonymously when it was negative, but in the case of a suspicious positive test result the person affected was only entitled to a confirmatory test, if helshe provided his/ her personal data to the doctor who transported the sample to the officially appointed laboratory to carry out the test and 
who, in the case of a confirmed positive result, was obliged to report the data to the National Public Health and Medical Officer Service for registration and to carry out contact persons' testing in the surrounding of the HIV-positive patient. In the mid-nineties a person made an individual petition to the Constitutional Court asking to revise the regulation which was in his opinion disproportionate and discriminatory whether it is lawful. On 28 June 2002 the Constitutional Court issued its statement in which they explained that the contested Decree contained significant restrictions on several fundamental rights and that this regulation was not on the appropriate level for that, since in Hungary such serious restrictions can only be ordained by an Act. Therefore, the Constitutional Court annulled the formally defective legislation from 31 December 2002, without examining the petitioner's substantive objections. In this way, the Constitutional Court followed its previous practice, allowed the legislatures-in this case the Parliament-sufficient time to prepare the new convenient Act to remedy the legal vacuum and uncertainty caused by the annulment. The Constitutional Court did not deal with the substantive defects of the annulled Decree which were supposed to be very strict because it was not a task in the case of a formally anti-constitutional matter. The Ministry of Health, Social and Family Affairs which drafted the new legislation chose the 'easier' solution and simply wanted to put the rules of the Decree into an Act without any changes because it was professionally correct. The proposed bill of the Act provoked great indignation not only among the members of the profession-doctors working with HIV-positive patients-and that of the NGOs, but the Data Protection Commissioner also voiced his dissatisfaction. The TASZ commented the draft of the Act and later, the bill also in the parliamentary stage, and sent the $18^{\text {th }}$ TASZ Position Paper, which contained their anxiety to MPs and that was sent to the press, too.

In consequence of the multidirectional actions, several significant changes were proposed to modify the bill and in December 2002, the followings were introduced into the epidemiological provisions of the Health Act. The possibility of the voluntary HIV screening was accepted as the main rule, to be carried out anonymously at the request of the person concerned; deviation from this rule was possible only in the very cases specified in the Act, namely if the person applying for screening belonged to one of the mandatory screening groups, further, it became also impossible to discriminate as to taking a patient into care on the basis of the presumable way of the infection and the institution of mandatory partner testing was abolished, too. It is important to emphasize once again that the proposed changes were included into the text of the original epidemiological provisions of the Decree, which shows that the legislator was still not able to break with the so-called traditional epidemiological model, which was outdated in many respects and totally unsuited to HIVI AIDS. Under that new Hungarian Act, HIV infection and AIDS were treated in the same way as all other epidemic diseases, which were very worrying as HIVIAIDS, unlike many other infectious diseases, was not transmitted through 'everyday' contact, and might be asso- 
ciated with social stigmas. Therefore, it was desirable in near future to prepare a specific law to control spreading of HIV and to protect HIV-positive patients. The recently adopted new Act, which was more respectful for the individuals right of self-determination, was not introduced as a result of a general change of attitude, but only was a result of the legislative pressure of the Constitutional Court and its more advanced content over the previous Decree was only due to the strong protests of the civil sector and the Data Protection Commissioner, too" [5].

The activities of the opponents were encouraged by the fact that since 1987 the Council of Europe has stressed adoption of voluntariness and anonymity, which proposal has been inconsistent with the rules of epidemiology. Under the great external and internal pressure, both our experts and our legislators step back.

"Under the new rules being in force since 1 January 2003, anyone can, with a few exceptions, voluntarily ask anonymous HIV testing. These exceptions are in connection with the members of the groups of persons who are obliged to be screened under the Health Act and therefore, they have not the right for sovereign decision whether or not to be tested and, in their case, screening must be carried out by name every time. On the other hand, the Act demands that when during the HIV test requested anonymously it becomes evident that the affected person belongs to one of the mandatory screening categories the examination can only go on, if the person discloses his or her identity. Discrimination concerning taking a person into care based on the presumed way of the infection and the institution of compulsory contact partner testing were also abolished" [5].

In addition to these, the Act also regulated the possibilities of returning home of a HIV-positive patient living abroad as well as it dealt with the possible criminal problems of HIV-infected and AIDS patients when they did not keep the (epidemiological) rules causing danger to anybody else.

\section{Our Judgement}

Our opinion is that homosexuality and the homosexuals were not a particular problem in our country in the past and these people did not suffer any disadvantages. Everybody could accept their existence although most of the inhabitants hardly understood their habit. Sexual life and its practices were a private matter, which were not the business of the outside world and were not publicly proclaimed. Besides these facts, medical doctors had to be informed about these deviations, because they could form a correct diagnosis only that way. Reading the report, it is clear for us that when our experts drafted the restrictive Decree they used the well-known classical epidemiological experiences, which were valid and effective in the cases of all communicable diseases.

Here we present just two examples. Both Salmonella typhi and Spirochaeta pallida caused serious epidemics and sporadic infections in our country at the beginning of the last century. In the case of abdominal typhus, different obliga- 
tory restrictions mentioned above, contact tracing and laboratory tests, as well as appropriate treatment and hygienic regulations with the use of the effective compulsory vaccine developed by Károly Rauss helped to reduce the number of cases. In the case of syphilis, until the 1950s, when the general use of penicillin started, serious compulsory restrictions, contact tracing, laboratory tests and Salvarsan treatment helped our experts to achieve almost total elimination of this disease, too [1] [2] [3] [4].

As it was mentioned before the acceptance of the original Decree provoked huge protests from those affected and their supporters, too. They could have only achieved their total goals with a new legislation and for that, it was necessary to find a reason. Since the protesters were not competent persons and were motivated by quite different, non-epidemiological considerations, unlike our health professionals, they found this reason in a unscientific definition, referring to the human rights, as follows: "HIVI AIDS infection is not transmitted through an ordinary everyday way (only by sexual contact or through blood, and certain secretions, etc.) and this transmission of the virus can be inhibited by simple basic hygienic rules and changing of manners" [5]. They therefore stated that classification of HIV/AIDS among the classical communicable disease was not justified and therefore the principles on the basis of which the patients were treated were exaggerated. This argument is not true because the transmission of HIV is hardly unique. This mode of transmission of viruses and bacteria-via sex, blood, secretions, contaminated syringes, etc.- - has long been known in cases of many diseases, such as hepatitis, lues, etc. Also, it is very interesting that the classification and control of the classic infectious diseases have never caused any problem for anyone and the use of the classical principles for their epidemiological control was very successful in each case. Since the domestic human rights activists have been acting on the basis of foreign examples, it is also clear that the legislation in the other countries of the world has also been missing professionally justified necessary regulations of epidemiological control. This fact explains why HIV/AIDS has spread and is still spreading rapidly across the globe causing more than 35.5 million infected patients and more than 10 million deaths and besides this, the cost of treating the infected patients is enormous for all states.

\subsection{Our Opinion about COVID-19 Pandemia}

The other epidemy which was studied by us is the recent pandemia caused by COVID-19. The virus broke out in China and it is certain that this virus causes respiratory infection and spreads mainly with droplets. Despite this, mask use and distance keeping were difficult to be introduced. Some people have supposed that the mask is not effective enough for protection; many still have found it uncomfortable and therefore do not want to wear it. Another delay was with applying the quarantine principle and the use of vaccines. As far as we know, it was only recognized in China, New Zealand and Australia the importance of strict isolation of all infected patients and of their contacts as well as of their 
screening from the beginning. In these countries in consequence of the consistent screening and strict isolation the spread of the virus was stopped and the epidemy was virtually eradicated. It is true that in the latter two countries this success was only temporary, as the imported viruses repeatedly caused new outbreaks due to the high number of unvaccinated inhabitants and the authorities could prevent the spread of the viruses only strict closures and accelerated vaccination. In China, however, the rigour and the quasi-obligatory vaccination have resulted in almost complete success. Only very few imported cases have been diagnosed and all people of the contaminated places/cities-their number may also be more million-have been very strictly closed, tested and immunized. You can see the epidemiological data in Table 1.

Table 1. Data to COVID-19 pandemia at the end of November in 2021 by WHO report.

\begin{tabular}{cccccc}
\hline Country & $\begin{array}{c}\text { Number of } \\
\text { inhabitants }\end{array}$ & $\begin{array}{c}\text { Number of ill } \\
\text { patients }\end{array}$ & $\begin{array}{c}\text { Number of } \\
\text { death }\end{array}$ & $\begin{array}{c}\text { \% of fully } \\
\text { immunized }\end{array}$ & $\begin{array}{c}\text { Death rate } \\
\text { in \% }\end{array}$ \\
\hline USA & 333.152200 & 48.282078 & 776.505 & 59.57 & 1.60 \\
UK & 65.375245 & 10.276011 & 145.140 & 68.08 & 1.41 \\
Germany & 83.129285 & 5.977208 & 102.178 & 68.43 & 1.70 \\
Austria & 8.976467 & 1.469208 & 12.120 & 65.26 & 0.82 \\
France & 64.431000 & 13.240304 & 126.530 & $?$ & 0.95 \\
Slovakia & 5.459780 & 697.102 & 14.602 & 46.13 & 2.09 \\
Sweden & 10.435447 & 1.207498 & 15.161 & 59.70 & 1.25 \\
Romania & 19.196200 & 1.780806 & 56.618 & 36.34 & 3.18 \\
Serbia & 6.271547 & 1.257025 & 11.744 & 44.70 & 0.93 \\
Slovenia & 2.108377 & 423162 & 5.586 & 54.70 & 1.32 \\
China & 1.411778000 & 128022 & 5.697 & 68.98 & 0.00 \\
Australia & 25.905238 & 211654 & 2.011 & 71.80 & 0.95 \\
New-Zealand & 5.131870 & 11525 & 44 & 70.17 & 0.38 \\
Israel & 9.435740 & 1.695512 & 8.295 & $\geq 90$ & 2.0 \\
Switzerland & 8.696088 & 1.627209 & 12.536 & $?$ & 0.77 \\
\hline
\end{tabular}

In 200 countries and territories around the world, the leaders and the population have been afraid of economic difficulties caused by the total quarantine, the danger of vaccines and certain other emotional problems, therefore total closure was not required, or was imposed late and in an imperfect form, and was ended prematurely, even several times. The result of this practice is that on 14th December 2021 the number of infected patients was 271,097,024 and 5,328,507 persons died, but still fewer than earlier in AIDS as HIV virus was more dangerous and the infected patients could not be treated with effective drug at the beginning and the epidemiological rules were not adequate. The injection of 
COVID-19 vaccines is not obligatory and the vaccination process has slowly started as well as it generally is not total yet-perhaps Israel is the only exception. One of the reasons for this situation in our country was the negative and false news were spread by opposition left and right parties, trade unions, human rights activists and the media. The other one is the ignorance. In consequence of this situation at present, about $36.3 \%$ of our population is still unvaccinated but $16,5 \%$ of them already recovered from COVID-19 infection. It is also a fact that egged crowds are demonstrating, protesting and rioting on the basis of human rights even against the simplest restrictions in different countries on the world. Therefore, it is understandable that the announcement of the universally compulsory vaccination is still delayed. Only the Austrian Government dared to announce at first that it would start in this February (The protests have started and are going on). Although, according to major foreign surveys, if somebody got only one vaccine injection significant protection developed in his/her organism. Therefore, we think that the only key of success is the compulsory more times repeated vaccination together with the acceptance of strict epidemiological regulations. Prolonged epidemy is not good for anyone, because more and more people will get ill and patients will go into hospital and die, besides this the economic losses have steadily increased [6] [7] [8] [9].

\section{Conclusion}

In conclusion, both examples show that the centuries-old scientifically established epidemiological rules are still valid today, but they have to be applied in time and in a correct manner. Furthermore, when incompetent funded "rights defenders" or political organizations referring to human rights have spread lies and have spoken against the experts-created epidemiological rules as well as the acceptance of vaccination, they have not only cheated everybody but they could also be accused by the crime of endangering of great mass of people which action can cause occasionally death, too! It has to be stated that the interests and rights of the total population are always over that of a single person and also realized that all pathogens live their own life among us according to their determinacy independently from our rights and interests!

\section{Conflicts of Interest}

The author declares no conflicts of interest regarding the publication of this paper.

\section{References}

[1] Fodor F. and Vedres I. (1981) K Közegészségtani és járványtani gyakorlatok és bemutatások. 3. jav. kiadás, Medicina Könyvkiadó, Budapest.

[2] Ralovich, B. (1993) Az emberi oltóanygok termelése és kontrollja Magyarországon. Konzilium, 2, 20-21.

[3] Ralovich, B. (1993) Zoonoses Surveillance System in Hungary. Country Report, WHO/OIE/IZS TE Workshop, Teramo, Italy. 
[4] Ralovich, B. (1997) Problems of Microbial Zoonoses in Hungary. Acta Microbiologica et Immunologica Hungarica, 44, 197-221.

[5] Csernus, E. (Szerk.) (2003) AIDS/HIV Magyarországon. TASZ.

[6] Ralovich, B. (2020) A koronavírusokkal-CoV—kapcsolatos gondolatok. Egészségtudomány, 64, 138-141.

[7] Moghadas, S.M., Vilches, T.N., Zhang, K., Wells, C.R., Shoukat, A., Singer, B.H., Meyers, L.A., Neuzil, K.M., Langley, J.M., Fitzpatrick, M.C. and Galvani, A.P. (2021) The Impact of Vaccinationon COVID-19 Outbreaks in the United States. https://doi.org/10.1101/2020.11.27.20240051

[8] Agrawal, U., Katikireddi, S.V., McCowan, C., Mulholland, R.H., Azcoaga-Lorenzo, A., Amele, S., Fagbamigbe, A.F., Vasileiou, E., Grange, Z., Shi, T., Kerr, S., Moore, E., Murray, J.L.K., Shah, S.A., Ritchie, L., O’Reilly, D., Stock, S.J., Beggs, J., Chuter, A., Torabi, F., Akbari, A., Bedston, S., McMenamin, J., Wood, R., Tang, R.S.M., de Lusignan, S., Richard Hobbs, F.D., Woolhouse, M., Simpson, C.R., Robertson, C. and Sheikh, A. (2021) COVID-19 Hospital Admissions and Deaths after BNT162b2 and ChAdOx1 nCoV-19 Vaccinations in 2.57 Million People in Scotland (EAVE II): A Prospective Cohort Study. https://www.thelancet.com/

[9] Sulayyim, H., Al-Noaemi, M., Alyami, M., Ahmad, S., Alyami, M., Alyami, H., Al-Swedan, A., Banihameem, I., Sedran, M., Al-Zubaidi, A. and Abbas, O. (2021) Epidemiology and Clinical Characteristics of the First 500 Positive Cases of COVID-19. A Multicenter Retrospective Study across the Najran Region of the Kingdom of Saudi Arabia (KSA). Open Journal of Epidemiology, 11, 222-236.

https://doi.org/10.4236/ojepi.2021.113019 